\title{
Nejčastější purpura s trochu jiným začátkem
}

\author{
prof. MUDr. Zdeněk Doležel, CSc., MUDr. Martin Jouza, MUDr. Marcel Schüller, Ph.D. \\ Pediatrická klinika LF MU a FN Brno
}

\begin{abstract}
Klíčová slova: purpura Schönlein Henoch, virus varicela zoster.
Key words: purpura Schönlein Henoch, virus varicella zoster.
\end{abstract}

Devátý den trvání varicely si matka 3,5leté dívky při večerní toaletě všimla, že dítě má na kůži v oblasti gluteální krajiny červenou kruhovitou linii a domnívala se, že jde nejspíše o následek související se sezením dítěte na WC. Následující den se však na kǔži dítěte v uvedené lokalizaci, ale také na dorzální straně obou stehen i na ventrální ploše obou bérců objevila načervenalá vyrážka, navíc si dítě stěžovalo na bolestivost plosek obou nohou. Při přijetí k hospitalizaci byla dívka afebrilní, uváděla měnlivé bolesti břicha a při vstupním vyšetření $1 \times$ zvracela nažloutlé zvratky. Fyzikálnímu nálezu dominovalo mírné symetrické perimaleolární prosáknutí, nevýrazný edém obou kolenních kloubů a dále pak nález na kưži, kde vedle plošných a zcela odloučených eflorescencí planých neštovic byla zřetelná linie červenofialového raše a dále četné morfy dobře palpovatelné purpury v lokalizaci uvedené $\vee$ predchozím textu (obrázek 1 a 2). Z pozměněných hodnot laboratorních vyšetření mělo dítě pouze leukocytózu $\left(15,5 \times 10^{9} /\right.$ I) s normálním diferenciálním rozpočtem, mírnou elevaci CRP (9 mg/l; norma 0-5) a mikroskopickou hematurii provázenou leukocyturií (nativní moč: ery 14, le 12). Stav jsme hodnotili jako purpuru Schönlein-Henoch (HSP). Za 24 hod. od prijetí došlo u dítěte $k$ zintenzivnění bolestí břicha s následným odchodem několika menších porcí stolice s príměsí čerstvé krve. Během dalších 48 hod. se dyskomfort zažívacího traktu zcela upravil, podle kontrolních vyšetření k výraznější
Obr. 1. Gluteálnípartie se zretetelnou linií WC sedátka, šipky označuji zaschlé morfy varicely

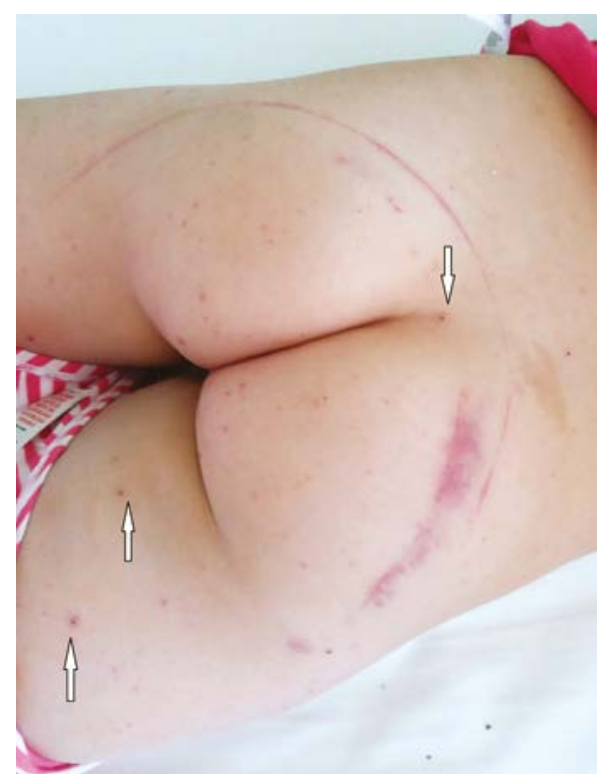

anemizaci dítěte nedošlo a také nález v moči byl před ukončením hospitalizace již negativní. Výsledky pomocných vyšetření (výtěr z krku, sérologie respiračních virů, ASLO, kultivace moči) byly zcela normální.

HSP charakterizuje klasická tetráda (netrombocytopenická lehce prominující purpura, artralgie, postižení zažívacího ústrojí a ledvin), přitom však současná př́tomnost všech těchto čtyř projevů není pro stanovení diagnózy nezbytná. Přes více než 150 letou historii HSP není doposud známo etiologické agens a stále je tak diskutována účast různých vyvolávajících činitelů (virové a bakteriální infekce, léky, autoimunita, chlad, ně-
Obr. 2. Typická purpura ventrální plochy levého bérce, šipky označují zaschlé morfy varicely

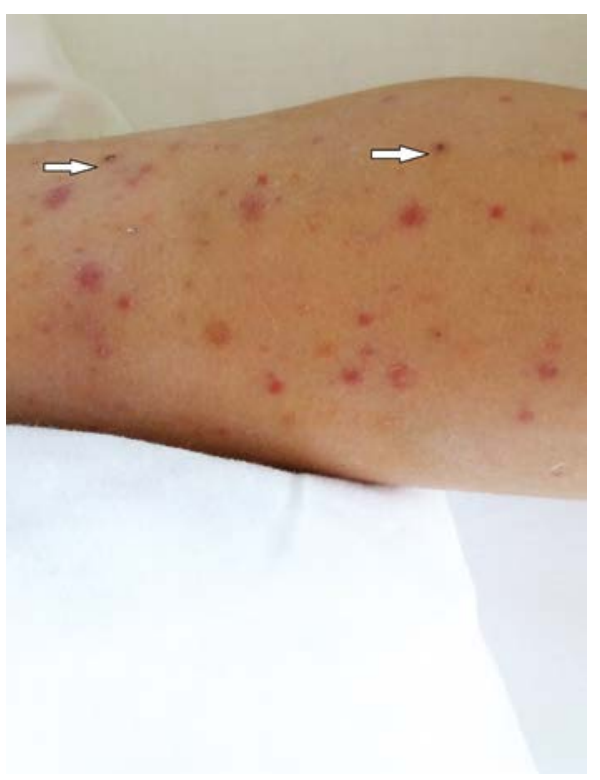

které potraviny). Účast viru varicela zoster (VZV) při rozvoji HSP je literárně uváděna jako velmi vzácná, přitom projevy HSP byly zaznamenány převážně kolem 10. dne trvání VZV infekce. Bez ohledu na tuto virovou infekci rozvoji purpury v typické lokalizaci (bérce, hýždě) u některých nemocných predchází červená vyrážka/ raš v místech, která jsou vystavena i relativně nižšímu mechanickému tlaku (elastický okraj spodního prádla nebo ponožek); u naší pacientky takovou krátkodobou kompresi způsobilo sedátko toaletní mísy.

Podpořeno: MZ ČR-RVO (FN Brno 65269705) 